Article

\title{
Bactericidal Effect of Clove Oil against Multidrug-Resistant Streptococcus suis Isolated from Human Patients and Slaughtered Pigs
}

\author{
Kanruethai Wongsawan ${ }^{1}$, Wasana Chaisri ${ }^{2}$, Sahatchai Tangtrongsup ${ }^{3,4} \mathbb{D}^{\mathbb{D}}$ and \\ Raktham Mektrirat $1,5, *$ (D) \\ 1 Department of Veterinary Biosciences and Public Health, Faculty of Veterinary Medicine, \\ Chiang Mai University, Chiang Mai 50200, Thailand; KanreuthaiW@gmail.com \\ 2 Department of Food Animal Clinics, Faculty of Veterinary Medicine, Chiang Mai University, \\ Chiang Mai 50200, Thailand; wasana.ch@cmu.ac.th \\ 3 Department of Companion Animal and Wildlife Clinic, Faculty of Veterinary Medicine, \\ Chiang Mai University, Chiang Mai 50200, Thailand; sahatchai.t@cmu.ac.th \\ 4 Research Center of Producing and Development of Products and Innovations for Animal Health and \\ Production, Chiang Mai University, Chiang Mai 50200, Thailand \\ 5 Research Center of Pharmaceutical Nanotechnology, Chiang Mai University, Chiang Mai 50200, Thailand \\ * Correspondence: raktham.m@cmu.ac.th; Tel.: +66-53-948046
}

Received: 28 November 2019; Accepted: 19 December 2019; Published: 21 December 2019

\begin{abstract}
Streptococcus suis is a zoonotic pathogen that is currently considered an emerging multidrug-resistant (MDR). Increasing antibiotic resistance can lead to the unsuccessful treatment of S. suis infection. Recently, many investigations of medicinal plants were conducted for the treatment of infection as a result of the increase of antibiotic-resistant bacteria. The aims of this study were to determine the chemical composition of essential oil from Syzygium aromaticum (L.) Merr. \& L.M. Perry and the antibacterial activities of clove oil on MDR S. suis. Using gas chromatography coupled to a mass spectrometer, eugenol $(97.76 \%)$ was found to be the major active ingredient of clove oil. In vitro antibacterial activities of clove oil against MDR S. suis were evaluated. Using the agar disc diffusion test, the clove oil showed a maximum zone of inhibition at $15 \%(\mathrm{v} / \mathrm{v})$ oil concentration. In a broth microdilution method, the minimum bactericidal concentration of clove oil against all MDR $S$. suis isolates was $0.1 \%(\mathrm{v} / \mathrm{v})$. A time-kill analysis was performed, and the killing kinetics of clove oil showed that MDR S. suis was completely reduced after $15 \mathrm{~min}$ of exposure to clove oil. In addition, clove oil exhibited a strong antibacterial activity at all $\mathrm{pH}$ values applied following incubation of MDR S. suis in $\mathrm{pH}$-adjusted media with clove oil. Moreover, scanning electron microscopy revealed the nonviable S. suis isolates clearly showed atypical form and cell membrane lysis after incubation with clove oil. This study confirms the efficacy of clove oil as a natural antimicrobial against MDR $S$. suis and suggests the possibility of employing it as a promising alternative product for control of infectious diseases caused by S. suis in animal and human patients.
\end{abstract}

Keywords: clove oil; Streptococcus suis; antibacterial activity; bactericidal activity

\section{Introduction}

Streptococcus suis is an emerging zoonotic pathogen that causes severe systemic infection in humans who come in close contact with pigs or pork-derived products. It also causes economic losses in the intensive swine industry. S. suis infections have been reported worldwide and a high human morbidity rate has been observed in Thailand, with the majority of infections caused by the consumption of raw pork [1]. 
The use of antimicrobial agents in veterinary medicine is essential to control infectious diseases. However, the development of resistance of $S$. suis has been increasingly reported [2-5]. The resistance of S. suis to antimicrobials commonly used in swine, including lincosamides (lincomycin and clindamycin), macrolides (erythromycin, spiramycin, and tylosin), sulfonamides, oxytetracycline, and tetracycline, has been acknowledged in many countries [4,6-8]. In human strains, resistance to tetracycline and macrolides has been reported since 2000 [9], and increased resistance rate has recently been reported in Asia [6,8,10-14]. Penicillin and cephalosporins have been considered the primary drugs of choice for S. suis infection. However, resistance to these drugs has been reported in many countries, including Thailand [4,11-13].

Thailand has the highest antibiotic resistance rates (with 100\% lincomycin and clindamycin resistance, and 90\% tetracycline and gentamycin resistance) compared with other Asian countries, and has the highest rate of penicillin resistance compared with other continents [13]. Currently, S. suis is considered a newly emerging multidrug-resistant (MDR) zoonotic pathogen [15-17]. This could lead to an unsuccessful treatment of $S$. suis infection and become a major public health concern. Thus, finding new and alternative antimicrobial compounds for the treatment of infectious diseases from medicinal plants is of particular interest.

During the last decade, medicinal plant investigations for the treatment of infectious disease have intensified due to the increase of antibiotic-resistant bacteria. Clove oil is extracted from the dried flower buds of clove (Syzygium aromaticum (L.) Merr. \& L.M. Perry). It has been used as a perfume and as a food flavoring [18]. Medicinally, it is widely used for reliving toothaches or cavity problems, asthma, rheumatoid arthritis, acne, scars, various allergic disorders, and as an antiseptic in oral infections $[19,20]$. Moreover, the antimicrobial properties of clove oil and its application to any product, such as food and health products, have been tested and have shown inhibitory activity on various pathogens, including Listeria monocytogenes, Campylobacter jejuni, Salmonella enteritidis, Bacillus cereus, Escherichia coli, and Staphylococcus aureus [21-25].

Although the antibacterial properties of clove oil have been previously reported, the study of its effect on MDR S. suis has been limitedly examined. The aims of this study were to determine the chemical composition of essential oil from clove buds and to investigate the antibacterial effects of clove oils on MDR S. suis. Our study revealed a strong potential bactericidal effect of clove oil against the swine pathogen MDR S. suis.

\section{Results}

\subsection{Chemical Compositions of Essential Oil}

The clove oil appeared as a clear pale yellowish liquid. The phytoconstituents were characterized by a GC-MS method with a running time of $55 \mathrm{~min}$. The chromatogram showed the presence of four identifiable spectra (Figure 1). A list of the constituents identified in the clove oil and their percentage composition are shown in Table 1 . The results demonstrated that the clove oil was composed of eugenol as the major component $(97.76 \%)$. Caryophyllene $(1.64 \%)$, gamma-humulene $(0.39 \%)$, and caryophyllene oxide $(0.78 \%)$ were observed as minor constituents. 


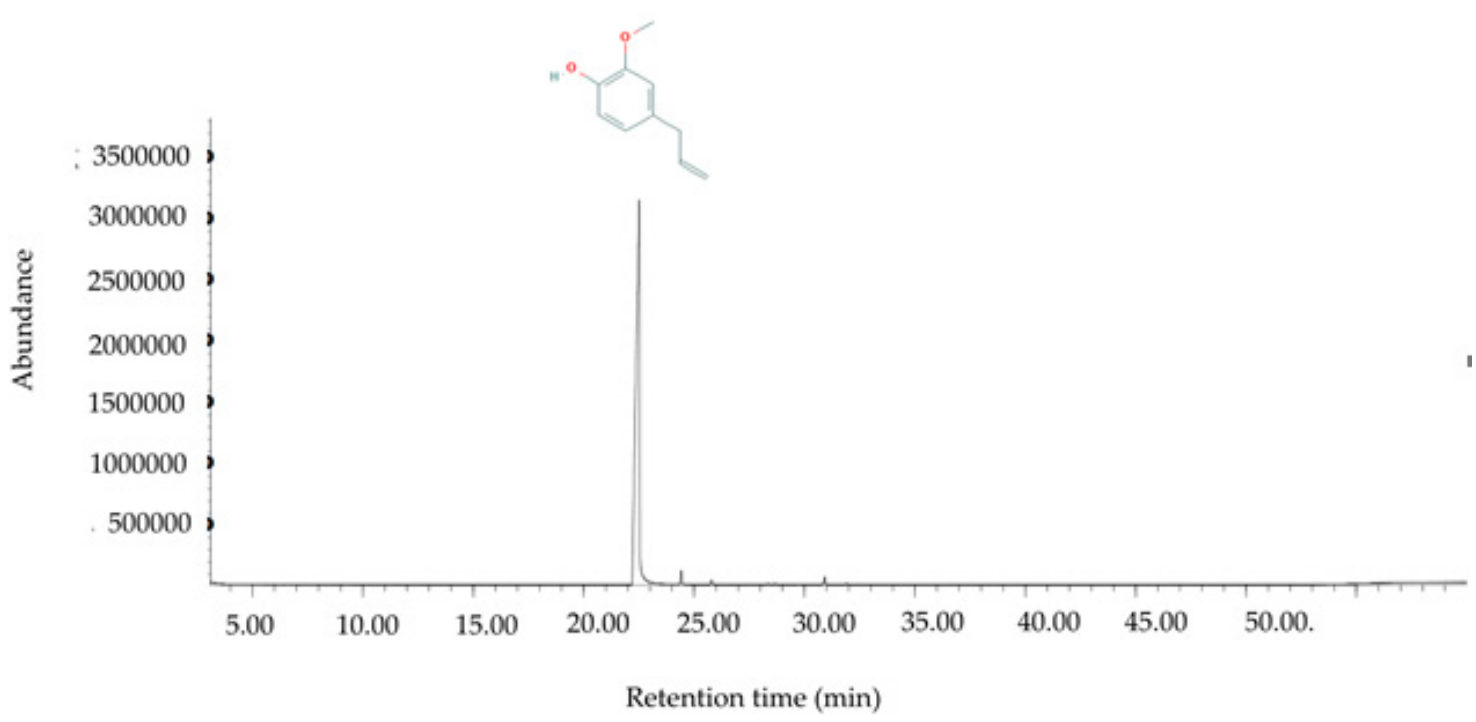

Figure 1. Gas chromatography-mass spectrometry (GC-MS) chromatograph for essential oil of $S$. aromaticum (L.) Merr. \& L.M. Perry.

Table 1. The chemical composition of essential oil from S. aromaticum (L.) Merr. \& L.M. Perry obtained by GC-MS analysis.

\begin{tabular}{cccccc}
\hline Peak & Retention Time & Phytoconstituents & Molecular Formula & Molecular Weight & Area (\%) \\
\hline 1 & 22.5156 & Eugenol & $\mathrm{C}_{10} \mathrm{H}_{12} \mathrm{O}_{2}$ & 164.20 & 97.7573 \\
2 & 24.4184 & Caryophyllene & $\mathrm{C}_{15} \mathrm{H}_{24}$ & 204.35 & 1.1647 \\
3 & 25.7996 & Gamma-humulene & $\mathrm{C}_{15} \mathrm{H}_{24}$ & 204.35 & 0.3944 \\
4 & 30.9152 & Caryophyllene oxide & $\mathrm{C}_{15} \mathrm{H}_{24} \mathrm{O}$ & 220.35 & 0.7836 \\
\hline
\end{tabular}

\subsection{Antibacterial Activity of Clove Oil}

Clove oil was found effective against all of the tested MDR S. suis isolates, as summarized in Table 2. The diameter of inhibition zones depended on the concentration of the oil. Maximum inhibition was found at $15 \%$ concentration, and the minimum effect was observed at $5 \%$ concentration. The inhibition zones were $5.07 \pm 0.12$ to $13.07 \pm 0.12 \mathrm{~mm}, 5.03 \pm 0.05$ to $14.03 \pm 0.05 \mathrm{~mm}$, and $8.00 \pm 0.00$ to $15.07 \pm 0.05 \mathrm{~mm}$ on discs impregnated with $5 \%, 10 \%$, and $15 \%(\mathrm{v} / \mathrm{v})$ oil, respectively. At $1 \%(\mathrm{v} / \mathrm{v})$, the oil could not inhibit any the tested isolates. As a positive control, high sensitivity to penicillin $(10 \mu \mathrm{g})$ was observed for all MDR S. suis strains. No inhibition zone was observed in the discs with methanol. This indicates that the methanol used to prepare the clove oil solution had no effect on bacterial growth.

\subsection{Determination of $M I C$ and $M B C$}

The minimum inhibitory concentration (MIC) and minimum bactericidal concentration (MBC) results are summarized in Table 2 and the distribution of MICs and MBCs for 15 isolates is shown in Table 3. The results showed that the MDR S. suis isolates were inhibited by clove oil at a very low concentration, with the $\mathrm{MIC}_{50}$ value at $0.05 \%$ and the $\mathrm{MIC}_{90}$ value at $0.1 \%$. The clove oil showed bactericidal effect against all tested MDR S. suis with the MBC values were $0.1 \pm 0.00 \%$. In addition, as a vehicle control, methanol was checked for its antibacterial capability at the various concentrations applied for preparing the essential oil in the experiment. We found that methanol at each concentration did not affect the growth of the tested isolates (data not shown). 
Table 2. Antimicrobial activity of clove oil against multidrug-resistant (MDR) S. suis.

\begin{tabular}{|c|c|c|c|c|c|c|c|}
\hline \multirow{3}{*}{$\begin{array}{l}\text { S. suis } \\
\text { Isolates }\end{array}$} & \multicolumn{5}{|c|}{ Inhibition Zone (mm) } & \multirow{3}{*}{$\begin{array}{c}\text { MIC } \\
(\% \mathrm{v} / \mathrm{v})\end{array}$} & \multirow{3}{*}{$\begin{array}{c}\text { MBC } \\
(\% \mathrm{v} / \mathrm{v})\end{array}$} \\
\hline & \multirow{2}{*}{$\begin{array}{l}\text { Penicillin } \\
\quad 10 \mu \mathrm{g}\end{array}$} & \multicolumn{4}{|c|}{ Clove Oil } & & \\
\hline & & $1 \%$ & $5 \%$ & $10 \%$ & $15 \%$ & & \\
\hline РCM01 & $33.20 \pm 0.24$ & $0.00 \pm 0.00$ & $0.00 \pm 0.00$ & $7.00 \pm 0.00$ & $13.00 \pm 0.00$ & $0.05 \pm 0.00$ & $0.1 \pm 0.00$ \\
\hline PCM02 & $15.00 \pm 0.00$ & $0.00 \pm 0.00$ & $7.13 \pm 0.23$ & $10.10 \pm 0.08$ & $15.00 \pm 0.00$ & $0.10 \pm 0.00$ & $0.1 \pm 0.00$ \\
\hline PCM04 & $17.30 \pm 0.47$ & $0.00 \pm 0.00$ & $5.07 \pm 0.12$ & $6.03 \pm 0.05$ & $8.00 \pm 0.00$ & $0.10 \pm 0.00$ & $0.1 \pm 0.00$ \\
\hline PCM06 & $32.01 \pm 0.09$ & $0.00 \pm 0.00$ & $8.00 \pm 0.00$ & $6.00 \pm 0.00$ & $11.07 \pm 0.05$ & $0.05 \pm 0.00$ & $0.1 \pm 0.00$ \\
\hline PLP03 & $15.00 \pm 0.00$ & $0.00 \pm 0.00$ & $7.00 \pm 0.00$ & $7.00 \pm 0.00$ & $15.03 \pm 0.05$ & $0.05 \pm 0.00$ & $0.1 \pm 0.00$ \\
\hline PLP06 & $45.00 \pm 0.00$ & $0.00 \pm 0.00$ & $0.00 \pm 0.00$ & $7.07 \pm 0.05$ & $14.00 \pm 0.00$ & $0.05 \pm 0.00$ & $0.1 \pm 0.00$ \\
\hline PCM05 & $45.00 \pm 0.00$ & $0.00 \pm 0.00$ & $0.00 \pm 0.00$ & $5.03 \pm 0.05$ & $12.10 \pm 0.08$ & $0.05 \pm 0.00$ & $0.1 \pm 0.00$ \\
\hline MNCM06 & $34.01 \pm 0.09$ & $0.00 \pm 0.00$ & $8.00 \pm 0.00$ & $12.00 \pm 0.00$ & $15.00 \pm 0.00$ & $0.05 \pm 0.00$ & $0.1 \pm 0.00$ \\
\hline MNCM07 & $35.00 \pm 0.00$ & $0.00 \pm 0.00$ & $7.23 \pm 0.21$ & $10.13 \pm 0.09$ & $15.00 \pm 0.00$ & $0.05 \pm 0.00$ & $0.1 \pm 0.00$ \\
\hline MNCM10 & $46.01 \pm 0.05$ & $0.00 \pm 0.00$ & $13.07 \pm 0.12$ & $12.23 \pm 0.17$ & $14.00 \pm 0.00$ & $0.05 \pm 0.00$ & $0.1 \pm 0.00$ \\
\hline MNCM43 & $33.00 \pm 0.00$ & $0.00 \pm 0.00$ & $5.00 \pm 0.00$ & $9.93 \pm 0.09$ & $10.00 \pm 0.00$ & $0.05 \pm 0.00$ & $0.1 \pm 0.00$ \\
\hline MNCM21 & $35.00 \pm 0.00$ & $0.00 \pm 0.00$ & $7.00 \pm 0.00$ & $9.00 \pm 0.00$ & $15.07 \pm 0.05$ & $0.05 \pm 0.00$ & $0.1 \pm 0.00$ \\
\hline MNCM25 & $40.00 \pm 0.01$ & $0.00 \pm 0.00$ & $8.13 \pm 0.12$ & $11.07 \pm 0.05$ & $15.00 \pm 0.00$ & $0.05 \pm 0.00$ & $0.1 \pm 0.00$ \\
\hline LPH5 & $39.00 \pm 0.02$ & $0.00 \pm 0.00$ & $8.00 \pm 0.00$ & $14.03 \pm 0.05$ & $11.03 \pm 0.05$ & $0.05 \pm 0.00$ & $0.1 \pm 0.00$ \\
\hline MNCM50 & $34.00 \pm 0.03$ & $0.00 \pm 0.00$ & $7.40 \pm 0.35$ & $8.10 \pm 0.08$ & $11.00 \pm 0.00$ & $0.10 \pm 0.00$ & $0.1 \pm 0.00$ \\
\hline
\end{tabular}

Table 3. Distribution of minimum inhibitory concentrations (MIC) and minimum bactericidal concentrations $(\mathrm{MBC})$ in 15 multidrug-resistant $S$. suis isolates.

\begin{tabular}{ccccc}
\hline $\begin{array}{c}\text { Clove Oil } \\
\text { Concentration (\%v/v) }\end{array}$ & $\begin{array}{c}\text { MIC Distribution } \\
\text { by the Number of } \\
\text { Isolates }\end{array}$ & $\begin{array}{c}\text { MBC Distribution } \\
\text { by the Number of } \\
\text { Isolates }\end{array}$ & MIC50/MBC50 & MIC90/MBC90 \\
\hline 0.0125 & 0 & 0 & & \\
0.025 & 0 & 0 & $0.05 / 0.1$ & $0.1 / 0.1$ \\
0.05 & 12 & 0 & \\
0.1 & 3 & 15 & \\
0.2 & 0 & 0 & \\
\hline
\end{tabular}

\subsection{Time-Kill Study}

To determine the killing kinetics of clove oil against MDR S. suis, survival of the MNCM06 isolate was evaluated over a $24 \mathrm{~h}$ period in the presence of clove oil at MBC. The data on CFU showed that treatment with $0.1 \%(\mathrm{v} / \mathrm{v})$ essential oil exhibited a strong bactericidal effect on the MNCM06 isolate in a rapid and time-dependent manner. The cell population was reduced by approximately 2-log CFU/mL after only $5 \mathrm{~min}$ of incubation. Within $15 \mathrm{~min}$, the bacterial population was completely inactivated (Figure 2, Table S1). Loss of viability was apparent for the MNCM06 isolate after prolonged exposure to the clove oil, while the growth rate was not decreased for the control without clove oil. 


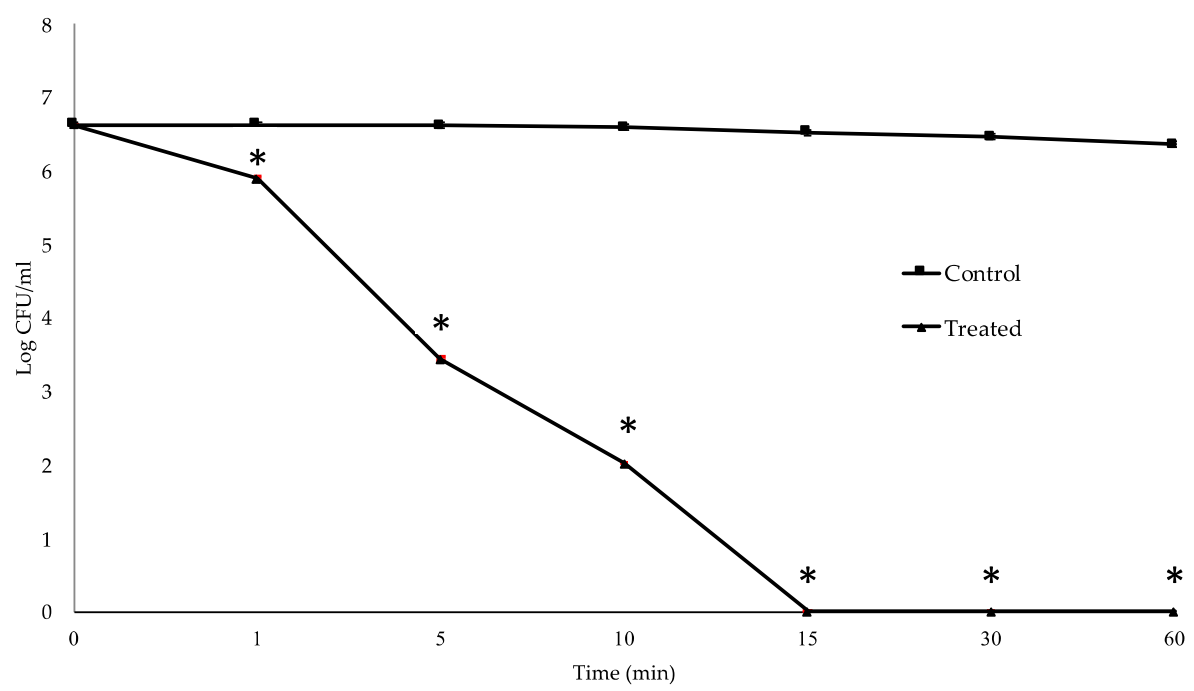

Figure 2. Effect of clove oil on MDR S. suis viability. Bacteria were suspended in phosphate-buffered saine (PBS) and incubated with or without oil (control) at MBC. Error bars represent the standard deviations from three independent experiments. ${ }^{*} p<0.05$.

\subsection{Effect of $\mathrm{pH}$ on Bactericidal Activity}

The highest bactericidal activity of clove oil was observed at $\mathrm{pH} 4$. However, the bactericidal effect at the same time of treatment were not significantly different $(p>0.05)$ among $\mathrm{pH}$ values applied (Figure 3, Table S2). The results show that at an MBC of $0.1 \%$, clove oil completely inhibited the tested isolate within $15 \mathrm{~min}$ of incubation, with a strong activity at $\mathrm{pH} 4$ through $\mathrm{pH} 8$. The growth of the tested isolate in the control tube without clove oil was unaffected by changes in $\mathrm{pH}$ value.

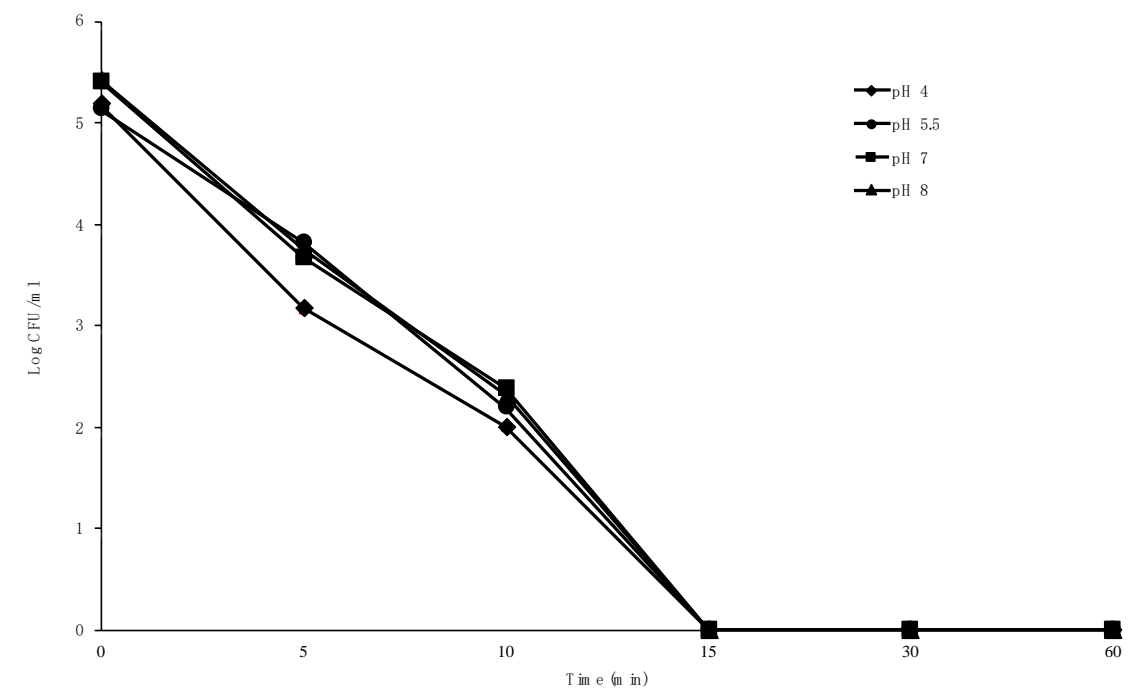

Figure 3. Effect of $\mathrm{pH}$ on the bactericidal activity of clove oil against MDR S. suis. Error bars represent the standard deviations from three independent experiments.

\subsection{Effect of Clove Oil on Cell Surface of S. suis}

The morphological changes of the treated bacteria were compared with the untreated control, as shown in Figure 4. The cell surface of the untreated MNCM06 isolate was found to have typical morphology, which is an intact spherical shape (Figure 4a). In contrast, the treatment of cells with clove oil for $1 \mathrm{~h}$ induced important morphological damage (Figure 4b-d). At the MIC and MBC of clove oil, it was found that cells became deformed, with cell wall ruptures and cell lysis in which leakage of cytoplasmic contents were apparent. 

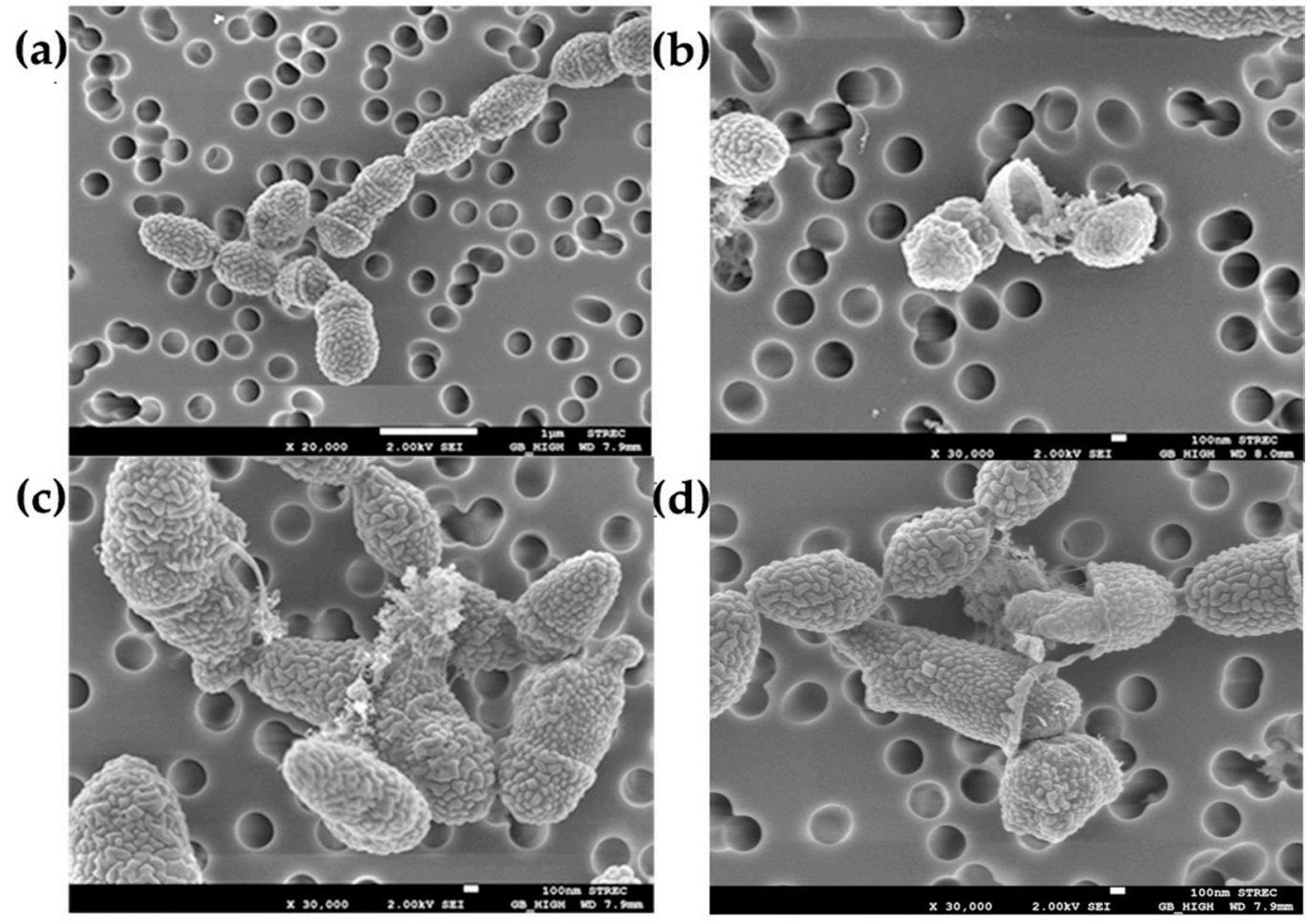

Figure 4. Scanning electron microscopic: (a) Image of MDR S. suis untreated cell; (b) after treatment with clove oil at the MIC, (c) and (d) after treatment with clove oil at the MBC. Scale: $1 \mu \mathrm{m}(\mathbf{a}), 100 \mathrm{~nm}(\mathbf{b}-\mathbf{d})$.

\section{Discussion}

Four phytoconstituents were identified in essential oil from clove buds in this study, and eugenol $(97.76 \%)$ was the major constituent. This is in agreement with previous studies that reported eugenol was the main component of clove $[22,26,27]$. However, the percentage of eugenol in those studies was different, ranging from $50.3 \%$ to $76.8 \%$. Our study obtained a higher eugenol content and found different components in the clove oil. The differences in the contents and components of the essential oil from clove buds can be explained as influences of the clove species, geographic region, environmental factors (temperature, humidity, and light) [28], and the difference in extraction methods used [27-29]. More importantly, the high concentration of eugenol in clove oil gives it potent bactericidal properties [30]. Moreover, the synergistic effects of phytochemicals are well-documented [31]. Interestingly, previous studies showed that the MIC of the purified eugenol is higher than the total clove oil [32]. Therefore, the antibacterial activity of clove is due to phytocomplexes of eugenol and the minor constituents.

The present study was performed on S. suis isolates, which are resistant to many antibiotics that are widely used to treat bacterial infections and used as feed additive in pigs to prevent infections in Thailand. The results from the agar disc diffusion method revealed that clove oil had inhibitory effects against all test MDR S. suis isolates. This is consistent with previous studies [33-36]. Incidentally, regarding the inhibition zones obtained from the essential oil, it is notable that differences can occur among studies due to the methods used in solubilizing the oils to obtain hydrophilic molecules [33], antimicrobial assays, and tested organisms. Even though the antibacterial properties of essential oil from clove bud against $S$. suis have already been reported [37], its effect against MDR S. suis has not been previously reported. Our findings suggest that the MDR S. suis isolated from both human patients and slaughtered pigs is susceptible to the essential oil of S. aromaticum (L) Merr. \& L.M.Perry.

The bacteriostatic and bactericidal activities of clove oil were assessed by determining the MIC and $\mathrm{MBC}$, respectively. The $\mathrm{MIC}_{90}$ and $\mathrm{MBC}_{90}$ values were $0.1 \%$, which indicates that the action of clove oil on MDR S. suis is bactericidal. The MIC/MBC values of clove oil obtained in this study were 
lower than in a previous study by Perugini Biasi-Garbin et al. [38], which reported 0.125 to $0.5 \%(\mathrm{v} / \mathrm{v})$, while Baskaran et al. [39] reported 0.4/0.8\% (v/v) on mastitis pathogen S. agalactiae. However, it should be noted that the initial bacterial load, culture medium used, incubation time, and temperature are important variables that can affect MIC determination of clove oil [40-43].

The time-kill study demonstrated rapid inhibition of bacterial growth within only 5 min of treatment with clove oil at MBC concentration (0.1\%). It was found that the clove oil reached maximal bactericidal effect within 15 min of incubation, when a complete loss of the viability of the MDR S. suis was observed. Our results are in accordance with a previous finding that the maximum kill rate of $S$. pneumoniae was observed during the first $15 \mathrm{~min}$ of eugenol exposure at $\mathrm{MBC}(0.12 \%)$ concentration [44] .However, it seems that $S$. suis was completely killed more rapidly than $S$. pneumoniae, which was completely killed within $60 \mathrm{~min}$ of exposure. This result suggests that clove oil has strong bactericidal activity on MDR S. suis and also indicates that MDR S. suis is very susceptible to clove oil.

With regard to the action of clove oil on MDR S. suis, the SEM images showed irregular morphology of cells treated with clove oil compared to untreated cells. Our results showed that cell breakdown is the principal phenomenon for MDR S. suis treated with clove oil. This corresponds to the result of the time-kill study, which demonstrated a progressive reduction in the number of viable S. suis cells in medium with clove oil and eventually led to complete death of the cells within $15 \mathrm{~min}$. Our findings on the action of clove oil on bacterial morphology are consistent with other studies [22,23,38,43-46]. It is already known from many research reports that the antibacterial activity of clove oil is due to its major component, eugenol. Eugenol is a phenolic structure that is highly active against various microorganisms [45]. It can readily pass through gram-positive bacterial cell walls, causing degradation of the cell wall [44], and then damage the cytoplasmic membrane, causing destruction of membrane proteins, impairment of bacterial enzyme systems, increased permeability leading to leakage of the cell contents, and eventually cell lysis [22,23].

Moreover, we described the results for the effect of $\mathrm{pH}$ on the bactericidal activity of clove oil against MDR S. suis, which showed strong antibacterial activity at all $\mathrm{pH}$ values applied, with the highest antibacterial activity observed at $\mathrm{pH}$ 4. Our result suggested that the bactericidal activity of clove oil against MDR S. suis is sustainable through neutral, acidic, and alkaline conditions. However, the variation of $\mathrm{pH}$ effect on the bactericidal activity of clove oil was reported in a previous study that found the highest activity of eugenol against Salmonella typhi at pH 9.0 [23], while Hoque et al. [47] reported the highest activity of clove oil against $L$. monocytogenes at $\mathrm{pH} 7.0$, and Knight et al. [48] showed strong inhibition of the growth of E. coli O157: $\mathrm{H7}$ at neutral (7.2) and acidic (4.5) pH values. The difference among these results could be due to factors such as test organisms, sample preparation, and the method used in $\mathrm{pH}$ assays. However, it is notable that the bactericidal effect of clove oil against MDR S. suis was not markedly inactivated by changes in $\mathrm{pH}$, which makes it valuable and possible to apply as a treatment or preventive therapy for S. suis infection.

In conclusion, this study found that clove oil exhibits a strong potential bactericidal effect on MDR S. suis, which suggests the possibility of employing it in a promising alternative product for control of infectious diseases caused by S. suis. Further research with in vivo studies and clinical trials need to evaluate the potential of clove oil in medical applications.

\section{Materials and Methods}

This study was performed at the Department of Veterinary Biosciences and Public Health, Faculty of Veterinary Medicine, Chiang Mai University, Thailand. The ethical approval by the Ethics Committee of the Faculty of Veterinary Medicine, Chiang Mai University, Thailand was waived since this study did not involve the study of human or animal subjects, data, or tissues.

\subsection{Bacteria and Culture Conditions}

The MDR S. suis isolates from storage at $-20{ }^{\circ} \mathrm{C}$ were used in the present study (Table 4). All of them were resistant to tylosin, enrofloxacin, tetracycline, trimethoprim-sulfamethoxazole, 
and oxytetracycline, which previously characterized antimicrobial resistance based on a breakpoint disc diffusion assay and a broth microdilution assay according to Clinical and Laboratory Standards Institute (CLSI) guidelines [49]. The bacterial strains were recovered from the bacterial storage medium by subculture on Columbia blood agar (Oxoid, Hampshire, U.K.) containing 5\% (v/v) defibrinated sheep blood and incubated at $37^{\circ} \mathrm{C}$ for $24 \mathrm{~h}$. The colonies were confirmed as S. suis by the API 20 Strep kit (BioMérieux, Marcy l'Etoile, France). All of them presented the same resistance pattern as described above.

Table 4. MDR S. suis isolates used in this study.

\begin{tabular}{|c|c|c|c|c|}
\hline \multirow{2}{*}{ S. suis Isolates } & \multirow{2}{*}{ Serotypes ** } & \multirow{2}{*}{$\mathrm{ST}^{+}$} & Genotype $\ddagger$ & \multirow{2}{*}{ Sources $\S$} \\
\hline & & & mrp/epf/sly & \\
\hline PCM01 & 2 & 104 & $+/-/-$ & healthy pig \\
\hline PCM02 & 7 & 373 & $+/-/+$ & healthy pig \\
\hline PCM04 & 7 & 89 & $-/-/+$ & healthy pig \\
\hline PCM06 & 9 & 16 & $-/-/-$ & healthy pig \\
\hline PLP03 & 16 & 374 & $-/-/-$ & healthy pig \\
\hline PLP06 & 16 & 375 & $-/-/-$ & healthy pig \\
\hline PCM05 & 16 & 376 & $-/-/-$ & healthy pig \\
\hline MNCM06 & 2 & 1 & $+/+/+$ & human \\
\hline MNCM07 & 14 & 11 & $+/ * /+$ & human \\
\hline MNCM10 & 2 & 25 & $+/-/-$ & human \\
\hline MNCM43 & 2 & 28 & $+/-/-$ & human \\
\hline MNCM21 & 2 & 101 & $-/-/+$ & human \\
\hline MNCM25 & 2 & 102 & $+/-/-$ & human \\
\hline LPH5 & 2 & 103 & $+/-/-$ & human \\
\hline MNCM50 & 2 & 104 & $-/-/+$ & human \\
\hline
\end{tabular}

${ }^{* *}$ Serotypes were identified by multiplex-polymerase chain reaction (PCR) combined with serum agglutination [50].

+ Sequence type (ST) were identified by Multilocus sequence typing (MLST) [50]. ‡ Virulence-associated gene profiles were identified by multiplex-PCR; $m r p$, muramidase-released protein; epf, extracellular factor; sly, suilysin; the variant of epf [50]. \$ All strains were recovered from stock kept at $-20^{\circ} \mathrm{C}$.

\subsection{Essential Oil and Characterization}

The essential oil of clove flower bud was purchased from Thai-China Flavours \& Fragrances Industry Co. (Thailand). Its chemical characterizations were analyzed using a gas chromatography-mass spectrometry (GC-MS) method. The GC-MS analysis was performed using an Agilent 6890 gas chromatograph in positive ion electron impact (EI, $70 \mathrm{eV}$ ) mode coupled to an Agilent 5973 mass selective detector (Agilent Technologies Inc, USA) with an HP-5MS column $(30 \mathrm{~m} \times 250 \mu \mathrm{m}$ i.d. $\times 0.25 \mu \mathrm{m}$ film thickness). The individual compound was identified by retention times relative to those of authentic samples and by matching the spectral peaks available in the Wiley, NIST, and NBS mass spectral libraries.

\subsection{Preparation of Clove Oil Concentration}

The clove oil was prepared aseptically in methanol as a $30 \%(\mathrm{v} / \mathrm{v})$ stock solution [23]. The concentrations used in subsequent experiments were prepared from the stock solution.

\subsection{Determination of Antibacterial Activity}

The antibacterial activity of clove oil was evaluated by disc diffusion method [23]. The MDR $S$. suis strains were inoculated into Bacto ${ }^{\mathrm{TM}}$ Todd-Hewitt broth (THB) medium (Becton Dickinson \& Co., Sparks, MD, USA) and grown for $18 \mathrm{~h}$ at $37^{\circ} \mathrm{C}$. Bacterial cultures were adjusted to a concentration of $1.5 \times 10^{8} \mathrm{CFU} / \mathrm{mL}$ using a McFarland densitometer (Grant Instruments, Cambridgeshire, UK) and were swabbed on BBL ${ }^{\text {TM }}$ Mueller-Hinton agar (MHA) (Becton Dickinson \& Co., Sparks, MD, USA) plates containing $5 \%(\mathrm{v} / \mathrm{v})$ defibrinated sheep blood. Sterile paper discs (Whatman no. 5, 6-mm 
diameter) were infused with $50 \mu \mathrm{L}$ of different concentrations of clove oil $(1 \%, 5 \%, 10 \%$, and $15 \%$ [v/v]). The airdried discs were placed on MHA plates and incubated overnight at $37^{\circ} \mathrm{C}$. Penicillin $(10 \mu \mathrm{g})$ was used as a positive control, and airdried discs of methanol were used as a vehicle control. The zones of inhibition were measured, and the determination was done in three independent experiments.

\subsection{Minimum Inhibitory Concentration (MIC) and Minimum Bactericidal Concentration (MBC)}

MIC and MBC were measured by the broth microdilution method. The inoculums were prepared by suspending bacteria of each isolate in $3 \mathrm{~mL}$ of sterile $0.85 \% \mathrm{NaCl}$ solution. Each suspension was adjusted to 0.5 using a McFarland densitometer and then diluted to 1:200 in BBL ${ }^{\mathrm{TM}}$ cation-adjusted Mueller-Hinton broth (CAMHB) (Becton Dickinson \& Co., Sparks, MD, USA) supplemented with 5\% $(\mathrm{v} / \mathrm{v})$ lysed horse blood. The cell density of the final inoculums was $5 \times 10^{6} \mathrm{CFU} / \mathrm{mL}$. Equal volumes $(100 \mu \mathrm{L})$ of bacterial suspension, and two-fold serial dilutions of clove oil in CAMHB supplemented with 5\% (v/v) lysed horse blood (0.2-0.0125\% final concentration) were mixed into the wells of 96-well plates. Control wells with no bacteria or no clove oil and methanol control were also prepared. After incubation for $24 \mathrm{~h}$ at $37^{\circ} \mathrm{C}$, MIC values were recorded as the lowest concentration of clove oil in which no visible growth occurred. To evaluate MBC values, $10 \mu \mathrm{L}$ of the content from each well showing no visible growth were dropped on MHA plates containing $5 \%$ (v/v) defibrinated sheep blood and then incubated for $24 \mathrm{~h}$ at $37^{\circ} \mathrm{C}$. The MBCs of clove oil were recorded as the lowest concentration at which no colony formation occurred. The MIC and MBC values were determined in triplicate and in three independent experiments. The MIC and MBC against 50\% (MIC50 and MBC50 values) and 90\% (MIC90 and MBC90 values) of isolates were also calculated.

\subsection{Time-Kill Study}

The MDR S. suis MNCM06 isolate was randomly selected as a representative strain to determine the killing kinetics of clove oil. The overnight culture of bacteria was harvested by centrifugation and suspended in sterile phosphate-buffered saline (PBS; $\mathrm{pH}$ 7.2). The suspension was adjusted to a concentration of $1.5 \times 10^{8} \mathrm{CFU} / \mathrm{mL}$ and treated with clove oil at MBC. A tube without essential clove oil was assigned as the control. Samples were taken at $0,5,10,15,30$, and $60 \mathrm{~min}$, then serially diluted in PBS (pH 7.2) and dropped in triplicate on Columbia blood agar plates containing 5\% (v/v) defibrinated sheep blood. Following $24 \mathrm{~h}$ of incubation at $37^{\circ} \mathrm{C}$, the colony-forming units (CFU) were calculated. The determination was done in three independent experiments.

\subsection{Effect of $\mathrm{pH}$ on Bactericidal Activity}

The effect of $\mathrm{pH}$ on the bactericidal activity of clove oil was determined as reported previously with slight modifications [51]. The $\mathrm{pH}$ was adjusted by adding $1 \mathrm{M}$ of $\mathrm{HCl}$ or $1 \mathrm{M}$ of $\mathrm{NaOH}$ to the THB to obtain various $\mathrm{pH}$ values $(4,5.5,7$, and 8$)$, sterilized by membrane filtration, and used immediately. The overnight culture of MDR S. suis MNCM06 isolate $\left(1.5 \times 10^{8} \mathrm{CFU} / \mathrm{mL}\right)$ was inoculated into $5 \mathrm{~mL}$ of pH-adjusted media with clove oil at MBC concentration, followed by incubation at $37^{\circ} \mathrm{C}$. Next, $100 \mu \mathrm{L}$ of the sample was taken, serially diluted in PBS (pH 7.2), and dropped in triplicate on Columbia blood agar plates containing 5\% (v/v) defibrinated sheep blood at regular time intervals $(0,15,30,60 \mathrm{~min})$. Following $24 \mathrm{~h}$ of incubation at $37^{\circ} \mathrm{C}$, the $\mathrm{CFU}$ was calculated. All the determinations were done in triplicate.

\subsection{Scanning Electron Microscopy (SEM)}

The effect of clove oil on the morphology of the MNCM06 isolate of MDR S. suis was further observed by SEM. Overnight culture of the bacteria was harvested by centrifugation, suspended in PBS ( $\mathrm{pH}$ 7.2), and then treated with clove oil at $\mathrm{MIC}$ and $\mathrm{MBC}$ for $1 \mathrm{~h}$ at $37^{\circ} \mathrm{C}$ and processed as previously described [22]. A control sample without clove oil treatment was similarly prepared and examined. 


\subsection{Statistical Analysis}

Data were analyzed and expressed as mean \pm SD of experiments performed in triplicate. The data for the effect of $\mathrm{pH}$ on bactericidal activity were analyzed using analysis of variance. Pairwise comparisons were analyzed using the least squares means procedure with Tukey's adjustment (values of $p<0.05$ ), and the statistical tests were performed using SAS 9.2 software.

Supplementary Materials: The following are available online at http://www.mdpi.com/2076-0817/9/1/14/s1, Table S1: Supplement data for time kill assay, Table S2: Supplement data for effect of $\mathrm{pH}$ on bactericidal activity of clove oil.

Author Contributions: All authors have read and agree to the published version of the manuscript. Conceptualization, K.W. and R.M.; Methodology, K.W. and R.M.; Validation, K.W., S.T. and R.M.; Formal analysis, K.W.; Investigation, K.W.; Resources, W.C.; Data curation, S.T.; Writing-original draft preparation, K.W.; writing-review and editing, K.W., S.T. and R.M.; Visualization, K.W.; Supervision, K.W.; Project administration, K.W.; Funding acquisition, K.W. All authors have read and agreed to the published version of the manuscript.

Funding: This research was funded by the private funding for research of Faculty of Veterinary Medicine, Chiang Mai University, Thailand, grant number R000012688.

Acknowledgments: This research work was partially supported by Chiang Mai University. We also thank the Research Center of Pharmaceutical Nanotechnology, Faculty of Pharmacy and Faculty of Veterinary Medicine, Chiang Mai University for facility support.

Conflicts of Interest: The authors declare no conflict of interest. The funders had no role in the design of the study; in the collection, analyses, or interpretation of data; in the writing of the manuscript, or in the decision to publish the results.

\section{References}

1. Takeuchi, D.; Kerdsin, A.; Pienpringam, A.; Loetthong, P.; Samerchea, S.; Luangsuk, P.; Khamisara, K.; Wongwan, N.; Areeratana, P.; Chiranairadul, P.; et al. Population-based study of Streptococcus suis infection in humans in Phayao province in Northern Thailand. PLoS ONE 2012, 7, e31265. [CrossRef] [PubMed]

2. Wisselink, H.J.; Veldman, K.T.; Van den Eede, C.; Salmon, S.A.; Mevius, D.J. Quantitative susceptibility of Streptococcus suis strains isolated from diseased pigs in seven European countries to antimicrobial agents licenced in veterinary medicine. Vet. Microbiol. 2006, 113, 73-82. [CrossRef] [PubMed]

3. Hendriksen, R.S.; Mevius, D.J.; Schroeter, A.; Teale, C.; Jouy, E.; Butaye, P.; Franco, A.; Utinane, A.; Amado, A.; Moreno, M.; et al. Occurrence of antimicrobial resistance among bacterial pathogens and indicator bacteria in pigs in different European countries from YEAR 2002-2004: The ARBAO-II study. Acta Vet. Scand. 2008, 50, 19. [CrossRef] [PubMed]

4. Zhang, C.; Ning, Y.; Zhang, Z.; Song, L.; Qiu, H.; Gao, H. In vitro antimicrobial susceptibility of Streptococcus suis strains isolated from clinically healthy sows in China. Vet. Microbiol. 2008, 131, 386-392. [CrossRef] [PubMed]

5. Princivalli, M.S.; Palmieri, C.; Magi, G.; Vignaroli, C.; Manzin, A.; Camporese, A.; Barocci, S.; Magistrali, C.; Facinelli, B. Genetic diversity of Streptococcus suis clinical isolates from pigs and humans in Italy (2003-2007). EuroSurveillance 2009, 14, 19310. [CrossRef] [PubMed]

6. Strangmann, E.; Fröleke, H.; Kohse, K.P. Septic shock caused by Streptococcus suis: Case report and investigation of a risk group. Int. J. Hyg. Environ. Health 2002, 205, 385-392. [CrossRef]

7. Vela, A.I.; Moreno, M.A.; Cebolla, J.A.; González, S.; Latre, M.V.; Domínguez, L.; Fernández-Garayzábal, J.F. Antimicrobial susceptibility of clinical strains of Streptococcus suis isolated from pigs in Spain. Vet. Microbiol. 2005, 105, 143-147. [CrossRef]

8. Hoa, N.T.; Chieu, T.T.B.; Nghia, H.D.T.; Mai, N.T.H.; Anh, P.H.; Wolbers, M.; Baker, S.; Campbell, J.I.; Chau, N.V.V.; Hien, T.T.; et al. The antimicrobial resistance patterns and associated determinants in Streptococcus suis Isolated from humans in Southern Vietnam, 1997-2008. BMC Infect. Dis. 2011, 11, 6. [CrossRef]

9. Ye, C.; Bai, X.; Zhang, J.; Jing, H.; Zheng, H.; Du, H.; Cui, Z.; Zhang, S.; Jin, D.; Xu, Y.; et al. Spread of Streptococcus suis sequence type 7, China. Emerg. Infect. Dis. 2008, 14, 787-791. [CrossRef] 
10. Ma, E.; Chung, P.H.; So, T.; Wong, L.; Choi, K.M.; Cheung, D.T.; Kam, K.M.; Chuang, S.K.; Tsang, T.; Collaborative study group on Streptococcus suis infection in Hong Kong. Streptococcus suis infection in Hong Kong: An emerging infectious disease? Epidemiol. Infect. 2008, 136, 1691-1697. [CrossRef]

11. Shneerson, J.M.; Chattopadhyay, B.; Murphy, M.F.; Fawcett, I.W. Permanent perceptive deafness due to Streptococcus suis type II infection. J. Laryngol. Otol. 1980, 94, 425-427. [CrossRef] [PubMed]

12. Huang, Y.T.; Teng, L.; Ho, S.W.; Hsueh, P.R. Streptococcus suis infection. J. Mirobiol. Immunol. Infect. 2005, 38, 306-313.

13. Varela, N.P.; Gadbois, P.; Thibault, C.; Gottschalk, M.; Dick, P.; Wilson, J. Antimicrobial resistance and prudent drug use for Streptococcus suis. Anim. Health Res. Rev. 2013, 14, 68-77. [CrossRef] [PubMed]

14. McEwen, S.A.; Fedorka-Cray, P.J. Antimicrobial use and resistance in animals. Clin. Infect. Dis. 2002, 34, S93-S106. [CrossRef] [PubMed]

15. Gottschalk, M.; Xu, J.; Calzas, C.; Segura, M. Streptococcus suis: A new emerging or an old neglected zoonotic pathogen? Future Microbiol. 2010, 5, 371-391. [CrossRef] [PubMed]

16. Lun, Z.-R.; Wang, Q.-P.; Chen, X.-G.; Li, A.-X.; Zhu, X.-Q. Streptococcus suis: An emerging zoonotic pathogen. Lancet Infect. Dis. 2007, 7, 201-209. [CrossRef]

17. Huang, J.; Ma, J.; Shang, K.; Hu, X.; Liang, Y.; Li, D.; Wu, Z.; Dai, L.; Chen, L.; Wang, L. Evolution and diversity of the antimicrobial resistance associated mobilome in Streptococcus suis: A probable mobile genetic elements reservoir for other streptococci. Front. Cell. Infect. Microbiol. 2016, 6, 118. [CrossRef]

18. Kalemba, D.; Kunicka, A. Antibacterial and antifungal properties of essential oils. Curr. Med. Chem. 2003, 10, 813-829. [CrossRef]

19. Kim, H.M.; Lee, E.H.; Hong, S.H.; Song, H.J.; Shin, M.K.; Kim, S.H.; Shin, T.Y. Effect of Syzygium aromaticum extract on immediate hypersensitivity in rats. J. Ethnopharmacol. 1998, 60, 125-131. [CrossRef]

20. Shapiro, S.; Meier, A.; Guggenheim, B. The antimicrobial activity of essential oils and essential oil components towards oral bacteria. Oral Microbiol. Immunol. 1994, 9, 202-208. [CrossRef]

21. Gill, A.O.; Holley, R.A. Disruption of Escherichia coli, Listeria monocytogenes and Lactobacillus sakei cellular membranes by plant oil aromatics. Int. J. Food Microbiol. 2006, 108, 1-9. [CrossRef] [PubMed]

22. Xu, J.-G.; Liu, T.; Hu, Q.-P.; Cao, X.-M. Chemical composition, antibacterial properties and mechanism of action of essential oil from clove buds against Staphylococcus aureus. Molecules 2016, 21, 1194. [CrossRef] [PubMed]

23. Devi, K.P.; Nisha, S.A.; Sakthivel, R.; Pandian, S.K. Eugenol (an essential oil of clove) acts as an antibacterial agent against Salmonella typhi by disrupting the cellular membrane. J. Ethnopharmacol. 2010, 130, 107-115. [CrossRef] [PubMed]

24. Vieira, B.B.; Mafra, J.F.; da Rocha Bispo, A.S.; Ferreira, M.A.; de Lima Silva, F.; Rodrigues, A.V.N.; Evangelista-barreto, N.S. combination of chitosan coating and clove essential oil reduces lipid oxidation and microbial growth in frozen stored tambaqui (Colossoma macropomum) fillets. LWT 2019, 116, 108546. [CrossRef]

25. Radünz, M.; da Trindade, M.L.M.; Camargo, T.M.; Radünz, A.L.; Borges, C.D.; Gandra, E.A.; Helbig, E. Antimicrobial and antioxidant activity of unencapsulated and encapsulated clove (Syzygium aromaticum, L.) essential oil. Food Chem. 2019, 276, 180-186. [CrossRef] [PubMed]

26. Jirovetz, L.; Buchbauer, G.; Stoilova, I.; Stoyanova, A.; Krastanov, A.; Schmidt, E. Chemical composition and antioxidant properties of clove leaf essential oil. J. Agric. Food Chem. 2006, 54, 6303-6307. [CrossRef]

27. Guan, W.; Li, S.; Yan, R.; Tang, S.; Quan, C. Comparison of essential oils of clove buds extracted with supercritical carbon dioxide and other three traditional extraction methods. Food Chem. 2007, 101, 1558-1564. [CrossRef]

28. Zobayed, S.; Afreen, F.; Kozai, T. Necessity and production of medicinal plants under controlled environments. Environ. Control Biol. 2005, 43, 243-252. [CrossRef]

29. Myint, S.; Wan Daud, W.R.; Mohamad, A.B.; Kadhum, A.A.H. Gas chromatographic determination of eugenol in ethanol extract of cloves. J. Chromatogr. B Biomed. Sci. Appl. 1996, 679, 193-195. [CrossRef]

30. Siddiqua, S.; Anusha, B.A.; Ashwini, L.S.; Negi, P.S. Antibacterial Activity of Cinnamaldehyde and Clove Oil: Effect on Selected Foodborne Pathogens in Model Food Systems and Watermelon Juice. J. Food Sci. Technol. 2015, 52, 5834-5841. [CrossRef]

31. Yang, Y.; Zhang, Z.; Li, S.; Ye, X.; Li, X.; He, K. Synergy effects of herb extracts: Pharmacokinetics and pharmacodynamic basis. Fitoterapia 2013, 92, 133-147. [CrossRef] [PubMed]

32. Nascimento Gislene, G.F.; Locatelli, J.; Freitas Paulo, C.; Silva Giuliana, L. Antibacterial activity of plant extracts and phytochemicals on antibiotic-resistant bacteria. Braz. J. Microbiol. 2000, 31, 247-256. [CrossRef] 
33. Nzeako, B.C.; Al-Kharousi, Z.S.; Al-Mahrooqui, Z. Antimicrobial activities of clove and thyme extracts. Sultan Qaboos Univ. Med. J. 2006, 6, 33-39. [PubMed]

34. Abdullah, B.H.; Hatem, S.F.; Jumaa, W. A comparative study of the antibacterial activity of clove and rosemary essential oils on multidrug resistant bacteria. UK J. Pharm. Biosci. 2015, 3, 18-22. [CrossRef]

35. Revati, S.; Bipin, C.; Chitra, P.B.; Minakshi, B. In vitro antibacterial activity of seven Indian spices against high level gentamicin resistant strains of enterococci. Arch. Med. Sci. AMS 2015, 11, 863-868. [CrossRef]

36. Dhara, L.; Tripathi, A. Antimicrobial activity of eugenol and cinnamaldehyde against extended spectrum beta lactamase producing Enterobacteriaceae by in vitro and molecular docking analysis. Eur. J. Integr. Med. 2013, 5, 527-536. [CrossRef]

37. de Aguiar, F.C.; Solarte, A.L.; Tarradas, C.; Luque, I.; Maldonado, A.; Galán-Relaño, Á.; Huerta, B. Antimicrobial activity of selected essential oils against Streptococcus suis isolated from pigs. Microbiologyopen 2018, 7, e00613. [CrossRef]

38. Perugini Biasi-Garbin, R.; Saori Otaguiri, E.; Morey, A.T.; Fernandes da Silva, M.; Belotto Morguette, A.E.; Armando Contreras Lancheros, C.; Kian, D.; Perugini, M.R.E.; Nakazato, G.; Durán, N.; et al. Effect of eugenol against Streptococcus agalactiae and synergistic interaction with biologically produced silver nanoparticles. Evid.-based Complement. Altern. Med. 2015, 2015. [CrossRef]

39. Ananda Baskaran, S.; Kazmer, G.W.; Hinckley, L.; Andrew, S.M.; Venkitanarayanan, K. Antibacterial effect of plant-derived antimicrobials on major bacterial mastitis pathogens in vitro. J. Dairy Sci. 2009, 92, 1423-1429. [CrossRef]

40. Bidlas, E.; Du, T.; Lambert, R.J.W. An explanation for the effect of inoculum size on MIC and the growth/no growth interface. Int. J. Food Microbiol. 2008, 126, 140-152. [CrossRef]

41. Smith, K.P.; Kirby, J.E. The inoculum effect in the era of multidrug resistance: minor differences in inoculum have dramatic effect on MIC determination. Antimicrob. Agents Chemother. 2018, 62, e00433-e00518. [CrossRef] [PubMed]

42. Pujol, I.; Guarro, J.; Sala, J.; Riba, M.D. Effects of incubation temperature, inoculum size, and time of reading on broth microdilution susceptibility test results for amphotericin B against Fusarium. Antimicrob. Agents Chemother. 1997, 41, 808-811. [CrossRef] [PubMed]

43. Yadav, M.K.; Park, S.-W.; Chae, S.-W.; Song, J.-J.; Kim, H.C. Antimicrobial activities of Eugenia caryophyllata extract and its major chemical constituent eugenol against Streptococcus pneumoniae. APMIS 2013, 121, 1198-1206. [CrossRef] [PubMed]

44. Nazzaro, F.; Fratianni, F.; De Martino, L.; Coppola, R.; De Feo, V. Effect of essential oils on pathogenic bacteria. Pharmaceuticals 2013, 6, 1451-1474. [CrossRef] [PubMed]

45. Bennis, S.; Chami, F.; Chami, N.; Rhayour, K.; Tantaoui-Elaraki, A.; Remmal, A. Eugenol induces damage of bacterial and fungal envelope. Moroc. J. Biol. 2004, 1, 33-39.

46. Kovács, J.K.; Felső, P.; Makszin, L.; Pápai, Z.; Horváth, G.; Ábrahám, H.; Palkovics, T.; Böszörményi, A.; Emődy, L.; Schneider, G. Antimicrobial and virulence-modulating effects of clove essential oil on the foodborne pathogen Campylobacter jejuni. Appl. Environ. Microbiol. 2016, 82, 6158-6166. [CrossRef] [PubMed]

47. Hoquea, M.M.; Barib, M.L.; Junejac, V.K.; Kawamotob, S. Antimicrobial activity of cloves and cinnamon extracts against food borne pathogens and spoilage bacteria, and inactivation of Listeria monocytogenes in ground chicken meat with their essential oils. Rep. Nat'l. Food Res. Inst. 2008, 72, 9-21.

48. Knight, K.P.; McKellar, R.C. Influence of cinnamon and clove essential oils on the D- and z-Values of Escherichia coli O157:H7 in apple cider. J. Food Prot. 2007, 70, 2089-2094. [CrossRef]

49. CLSI. Performance Standards for Antimicrobial Susceptibility Testing, 28th ed.; Clinical and Laboratory Standards Institute (CLSI): Wayne, PA, USA, 2018.

50. Wongsawan, K.; Gottschalk, M.; Tharavichitkul, P. Serotype- and virulence-associated gene profile of Streptococcus suis isolates from pig carcasses in Chiang Mai province, Northern Thailand. J. Vet. Med. Sci. 2015, 77, 233-236. [CrossRef]

51. Ohno, T.; Kita, M.; Yamaoka, Y.; Imamura, S.; Yamamoto, T.; Mitsufuji, S.; Kodama, T.; Kashima, K.; Imanishi, J. Antimicrobial activity of essential oils against Helicobacter pylori. Helicobacter 2003, 8, 207-215. [CrossRef]

(C) 2019 by the authors. Licensee MDPI, Basel, Switzerland. This article is an open access article distributed under the terms and conditions of the Creative Commons Attribution (CC BY) license (http://creativecommons.org/licenses/by/4.0/). 